DOI https://doi.org/10.18551/rjoas.2018-09.30

\title{
CAPITAL STRUCTURE, INVESTMENT OPPORTUNITY SET, DIVIDEND POLICY AND PROFITABILITY AS A FIRM VALUE DETERMINANTS
}

\author{
Sudiani N.K.A., Wiksuana I G.B. \\ University of Udayana, Indonesia \\ *E-mail: ayu sudiani@yahoo.co.id
}

\begin{abstract}
The purpose of this study was to determine the effect of capital structure, investment opportunity set, dividend policy and profitability on the value of manufacturing companies in the Indonesia Stock Exchange. The populations in this study were all manufacturing companies on the Indonesia Stock Exchange totaling 146 companies in the 2013-2016. The sample determination technique used was purposive sampling, so the final sample obtained was 24 companies incorporated in manufacturing companies on the Indonesia Stock Exchange. The data analysis technique used is multiple linear regression analysis with the help of SPSS 22 for Windows application. Based on the results of the analysis shows that: investment opportunity set, dividend policy, and profitability have an influence on the firm value, while the capital structure does not have an influence on the value of manufacturing companies in the Indonesia Stock Exchange.
\end{abstract}

\section{KEY WORDS}

Capital structure, investment, opportunity, dividend policy, profitability, firm value.

The firm value is the investor's perception of the company. The firm value is very important because it reflects the company's performance that can affect investor perceptions of the company. Investor perception on the level of success of the company is reflected through the firm value. Investors who invest their funds in the capital market not only have short-term goals, but also earn long-term income. Investors must utilize all information to analyze the market and invest in the hope of gaining profit (Budiandriani and Mahfudnurnajamuddin, 2014).

Firm value can be influenced by external and internal factors. According to Sujoko and Soebiantoro (2007), external factors are variables that cannot be controlled by the company while internal factors are a set of variables that can be controlled by a company which is often seen as an important factor for determining firm value. The company's internal factors in capital market analysis are often referred to as the company's fundamental factors; this factor is controllable so that it can be controlled by the company. External variables that affect firm value such as exchange rates, inflation, and government policies and so on. Internal variables that affect firm value are financial decisions consisting of funding decisions, investment decisions, and dividend policies. These three financial decisions will maximize the firm value which will further increase the wealth of shareholder wealth.

The firm value can provide maximum prosperity to shareholders if the stock price increases. The higher the share prices of a company, the higher the prosperity of its shareholders. Firm value is an indicator for the market in providing an overall assessment of the company (Salvatore 2011: 10). The success of creating firm value gives hope to shareholders in the form of greater profits (Salvatore 2011: 12). Firm value is measured by Price Book Value (PBV) which is the market ratio used to measure the performance of stock market prices on the value of the book (Robert in Kusumajaya, 2011).

The trade-off theory predicts a positive relationship between capital structure and firm value assuming that tax returns are still greater than the costs of financial pressure and agency costs. Trade-off theory also predicts a positive relationship between capital structure and the level of profitability or financial performance of a company. Reducing debt interest on the calculation of taxable income will reduce the proportion of tax burden, so that the proportion of net income after tax becomes greater, or the level of profitability is higher. 
Research conducted by Velnampy and Niresh (2012), Aggarwal and Padha (2017), Hermuningsih (2013), Purwanto and Agustin (2017), Winarto (2015), Rehman (2016), Kouki and Hatem (2011), Juhandi, et al (2013), Sudiyatno, et al (2012) prove that capital structure has a positive effect on firm value significantly. This conclusion is different from the results of Safrida (2008) and Suguhen (2003), Cheryta et al (2017), Mahdaleta, et al (2016), Rasyid (2015), Manjunatha (2013), Manurung (2014), Sujoko and Soebiantoro (2007) who find evidence that the capital structure does not affect the firm value.

Increased firm value is the result of evaluating good investment opportunities before. Future investment options and a combination of asset placement are the understanding of the company as seen from the decomposition of the investment opportunity set by Myers (1977). Company spending will determine in the future from the firm value (Zahro, 2009). Rising investment opportunities accompanied by good corporate performance will increase the higher cash flow that will be used again to get high investment opportunities.

The theory that deals with the influence of dividend policy and firm value, is the dividend irrelevance theory and the bird-in-the-hand theory, both of which contradict each other. According to the dividend irrelevance theory recommended by Merton Miller and Franco Modigliani (1958) in Brigham (2001: 66), it is said that dividend policy does not have an effect on both the firm valueand its capital costs. They argue that the value of a company will only be determined by its basic ability to generate profits and business risks, in other words, the value of a company depends solely on the income generated by its assets, not on how the income is divided between dividends and retained earnings. In contrast to irrelevance theory, according to the bird-in-the hand theory proposed by Myron Gordon and John Lintner (1959) in Brigham (2001: 67), which states that the value of a company will be maximized by a high dividend payout ratio, because investors consider that The risk of dividends is not as high as the increase in capital costs, so investors prefer profits in the form of dividends rather than the expected profits from the increase in capital value.

\section{LITERATURE REVIEW}

The firm value is very important because it reflects how much the company can provide benefits to investors. The higher the value of the company, the greater the prosperity that the owner of the company will receive (Wiagustini, 2014: 8). Originally the company's theory was based on the assumption that the company's purpose or objective was to maximize current or short-term profits. However, based on observations companies often sacrifice short-term profits to increase future or long-term profits. Because both short-term and long-term profits are very important, the company's theory (theory of the firm) now postulates that the main purpose or goal of the company is to maximize wealth or firm value. This is reflected in the present value of all expected corporate profits in the future.

The company's capital structure is permanent financing which consists of long-term debt, preferred stock and shareholder capital. The company's goal in the long run is to optimize the value of the company by minimizing the company's capital costs. Determining the optimal target capital structure is one of the main tasks of the company's management. Capital structure is equity and debt funding in a company. The capital structure is the proportion of the company's debt financing, namely the company's laverage ratio. The capital structure has the key to improving productivity and company performance. Capital structure theory explains that the company's financial policy in determining the capital structure (mix between debt and equity) aims to optimize the firm value.

The term Investment Opportunity Set (IOS) was first introduced by Myers (1997). According to Myers (1997) Investment Opportunity Set (IOS) is an investment decision indicator in the form of a combination of assets in place and investment choices that will come with a positive Net Present Value (NPV) that will affect the company's value. According to Gaver and Kenneth (in Hasnawati, 2005: 118) Investment Opportunity Set (IOS) is the value of a company whose amount depends on expenditures set by management in the future, which is currently the investment choices that are expected to return the big one. In general, it can be said that the IOS describes the extent of investment opportunities or 
opportunities for a company, but it depends on the company's expenditure choice for future interests. The growth potential of a company can be demonstrated by the existence of investment opportunities that can produce higher profits in the future (Jati, 2003). Thus the IOS is not observable so that a proxy needs to be selected which can be linked to other variables.

Dividends are distributions, which can take the form of cash, other assets, letters or other evidence stating the company's debt, and shares, to the shareholders of a company as a proportion of a number of shares owned by the owner. While the dividend policy (dividend policy) is a decision to determine how much part of the company's income that will be distributed to shareholders and who will be reinvested (reinvestment) or retained (retained) in the company. From this definition, dividend policy is based on a range of considerations between the interests of shareholders on the one hand and the interests of the company on the other (Ang, 1997). Dividends are distributed to shareholders as earnings after tax or after-tax income from company profits. And the amount or percentage of profit or income that will be paid by the company to shareholders as cash dividends is called the dividend payout ratio. So we can conclude that the higher the DPR of a company, the higher the amount of profit that will be paid as dividends to shareholders. According to Robert Ang (1997), dividend payout ratio is the ratio between dividends per share and earnings per share. So perspective is seen as dividend growth per share on the growth of earnings per share. There are several opinions and theories described above used as guidelines and references, which theories are relevant and in accordance with the policies or conditions of each company and country.

Corporate profitability is one way to assess precisely the extent of return that will be obtained from investment activities. Profitability is the company's ability to generate profits and measure the level of operational efficiency and efficiency in using its assets (Chen, 2004). In this case it can be explained to know the profitability of a company is very important for investors and creditors. According to Sartono (2001: 122) profitability is the company's ability to make a profit in relation to sales, total assets and own capital. Whereas according to Munawir (1995: 31) in Martalina (2011) profitability is the company's ability to generate profits in a certain period. From these two definitions it can be concluded that what is meant by profitability is the company's ability to generate profits during a certain period that can be calculated based on sales or assets or own capital.

Hypotheses:

$\mathrm{H} 1$ : Capital structure has a positive and significant effect on the firm value;

$\mathrm{H} 2$ : Investment Opportunity Set has a positive and significant effect on firm value;

H3: Dividend policy has a positive and significant effect on the firm value;

$\mathrm{H} 4$ : Profitability has a positive and significant effect on firm value.

\section{METHODS OF RESEARCH}

The population in this study was all 146 manufacturing companies on the Indonesia Stock Exchange in 2013-2016. The sample determination technique used in this study is nonprobability sampling with purposive sampling technique, which is a sample determination technique with certain considerations (Sugiyono, 2013: 120). The total manufacturing companies listed on the Indonesia Stock Exchange (IDX) for the period 2013-2016 were 146 companies and the total companies that did not distribute dividends continuously during the 2013-2016 were 122 companies. The final sample is 24 manufacturing companies listed on the Indonesia Stock Exchange (BEI) for the 2013-2016. Data collection methods used in this study are non-participant observations, namely data collection techniques by recording the data needed in manufacturing companies listed on the IDX for the period 2013-2016 where researchers are not directly involved in company activities and only as observers independent. The data needed in the form of financial statements of manufacturing companies obtained from ICMD products and www.idx.co.id. In this study used multiple linear analysis techniques to determine the effect of capital structure, investment opportunity 
set, dividend policy, and profitability on firm value in the 2013-2016 with the help of SPSS (Statistical Package for Social Science) version 22.0 for Windows.

\section{RESULTS OF STUDY}

The analysis model used in this study is multiple linear regression analysis. This analysis is used to determine whether there is influence between independent variables, namely Capital Structure (DER) (X1), Investment Opportunity Set (MBVE) (X2), Dividend Policy (DPR) (X3) and Profitability (ROE) (X4), against variables bound is the company value $(\mathrm{Y})$ which is proxied by the price book value at manufacturing companies in the Indonesia Stock Exchange for the period 2013-2016. To facilitate data processing, the SPSS program is used. The summary of regression analysis results can be seen in Table 1 below:

Table 1 - Multiple Linear Analysis

\begin{tabular}{|c|c|c|c|c|c|}
\hline \multirow{2}{*}{ Model } & \multicolumn{2}{|c|}{ Unstandardized Coefficients } & \multirow{2}{*}{$\begin{array}{l}\text { Standardized Coefficients } \\
\text { Beta }\end{array}$} & \multirow{2}{*}{$\mathrm{t}$} & \multirow{2}{*}{ Sig. } \\
\hline & B & Std. Error & & & \\
\hline (Constant) & $-3,885$ & ,815 & & $-4,768$ &, 000 \\
\hline DER &, 009 &, 006 & ,085 & 1,577 & ,119 \\
\hline $1 \mathrm{IOS}$ & ,006 & ,001 & ,236 & 4,356 &, 000 \\
\hline DPR & ,009 &, 005 & ,099 & 1,995 & ,050 \\
\hline ROE & ,371 &, 023 & ,818 & 15,881 &, 000 \\
\hline
\end{tabular}

Source: Primary data, 2018.

Based on Table 1, we can obtain multiple linear line equations as follows:

$$
Y=-3,885+0,009 X_{1}+0,006 X_{2}+0,009 X_{3}+0,371 X_{4}
$$

Based on the results of the study, it was found that the capital structure had a positive but not significant effect on the value of the company in manufacturing companies in the Indonesian stock exchange in the 2013-2016, so it can be concluded that the capital structure does not affect the value of the company. That is, a rise or fall or a high level of debt of a company will not affect the value of the company. The reason for the capital structure does not affect the value of the company because the size of the debt is not the only factor that influences investors' decisions in investing, but there are other factors that are taken into consideration by investors, including profit or profitability level of the company. Not influencing the level of debt to the value of the company should encourage companies to be better at managing the funds owned by the company. Because, what is of concern to investors is not the high and low level of debt, but how the company manages the source of these funds to achieve maximum profit that can increase the prosperity of shareholders. Thus, the increase in shareholder prosperity will be in line with the increase in the value of the company. The findings are also consistent with the results of Safrida (2008) and Suguhen (2003), Sulistiono (2010), Cheryta et al (2017), Mahdaleta et al (2016), Rasyid (2015), Manjunatha (2013), Manurung (2014), Sujoko and Soebiantoro (2007) who found evidence that capital structure has no effect on firm value.

Based on the results of the study, it was found that IOS had a positive and significant effect on the value of the company in manufacturing companies in the Indonesian stock exchange period 2013-2016. Market to Book Value of Equity is an IOS proxy based on prices that sees the company's growth from the company's ability to obtain and manage capital. For this reason, these results provide an understanding that investment opportunities that are seen from the company's ability to obtain and manage capital have a positive and significant effect on the value of the company. IOS will provide information about the prospects of future income. The results show that if the IOS increases, the value of the company will increase due to the higher opportunities the company has to invest and are expected to get a higher return. IOS shows the company's growth potential, so that it becomes an attraction for investors because it will benefit investors in the future. The results of this study are in line 
with Hasnawati's research (2005: 123), Pratiska (2012), Wijaya and Bandi (2010), Pujiati and Widanar (2009), Nasrum (2013), Slater and Zwirlein (1996), Hasnawati (2005), Wijaya and Wibawa (2010), Rachmawati and Triatmoko (2007), Tito Perdana Putra, et al (2007) and Pratiska (2012) who found that IOS had a positive and significant effect on firm value (price book value).

Based on the results of the study, it was found that dividend policy has a positive and significant influence on firm value in manufacturing companies in the Indonesia stock exchange for the 2013-2016 period, so it can be concluded that the higher the dividend payout ratio, the higher the company value will be. Because, the high dividend payment will cause a positive reaction from investors which will be reflected in the increase in stock prices. The above results are in line with signaling theory which states that investors consider changes in dividends as a sign of management's estimates of profits. Thus, the increase in dividends is a signal that the company predicts a good income in the future, and vice versa. Keown (2000) states that a company's dividend policy includes a dividend payout ratio that shows the amount of dividends paid relative to company income and the stability of dividends over time. The results of previous studies regarding the effect of dividend policy on company value were carried out by Ashamu et al. (2012), Fenandar and Raharja (2012), Rehman (2016), Guizani, et al (2012), Anton (2016), Nwamaka (2017), Malik, et al (2015), Budagaga (2017), Vidhya and Mohanasundari (2016 ), Winarto (2015), Darmawan (2012), Juhandi, et al (2013) found that dividend policy has a positive effect on firm value.

Based on the results of the study, it was found that profitability had a positive and significant effect on the value of the company in manufacturing companies in the Indonesia stock exchange for the 2013-2016 period. This means that if profitability increases, the value of the company will also increase. The results of research from Suprantiningrum and Sabat (2013), the higher the ROE, the higher the price book value is as a measure of the value of the company because investors will buy shares and will be more interested in ROE or part of their total profitability to shareholders. In line with research, Wirawati (2008), Marangu and Ambrose (2014), and Nurhayati (2013), Dewi, et al. (2014), Nurmalasari (2002), Ali (2009), Ayuningtias (2013), Mardiyati et al. (2010), Aggarwal and Padha (2017), Hermuningsih (2013), Sabrin, et al. (2016), Cheryta, et al. (2017), Rasyid (2015), Winarto (2015), Manurung, et al. (2014), Putu, et al (2014) that the amount of profits obtained by a company through its capital will increase the value of the company.

\section{CONCLUSSION AND SUGESTIONS}

Capital Structure has a positive but insignificant effect on the value of the company in manufacturing companies in the Indonesia Stock Exchange in the 2013-2016 period, so it can be concluded that the capital structure does not affect the value of the company which means that the rise and fall of a company's debt will not affect the value of the company due to high low debt is not the only factor that influences investors' decisions in investing.

Investment Opportunity Set has a positive and significant effect on the value of the company in manufacturing companies in the Indonesia stock exchange for the 2013-2016 period, these results prove that if the IOS increases, the value of the company will increase due to the higher opportunities the company has to invest.

Dividend policy has a positive and significant influence on the value of the company in manufacturing companies in the Indonesian stock exchange for the 2013-2016 period, these results prove that shareholders prefer to share profits in the form of dividends compared to the distribution of profits in the form of capital gains.

Profitability has a positive and significant effect on the value of the company in manufacturing companies in the Indonesia stock exchange for the 2013-2016 period, these results prove that the higher the value of profit obtained, the higher the value of the company.

It is recommended to companies, determining the capital structure by using debt at a certain level (as far as greater benefits, additional debt is still allowed) as a source of funding can increase the value of the company. The IOS variable that shows the company's growth potential, so that it becomes an attraction for investors because it will benefit investors in the 
future. By increasing the Dividend Payout Ratio (DPR), the greater the dividend divided will further increase the share price which also increases the value of the company. With high profit, it will give an indication of good company prospects so that it can trigger investors to participate in increasing stock demand.

With the existence of one independent variable in this study that is insignificant, which is due to the fact that this research is purely only using internal factors or fundamental factors of the company based on information in the company's financial statements, it is suggested that the next researcher use the profitability variable as a mediating variable between capital structure and firm value.

Subsequent research is expected to be able to use a larger number of samples, so that the results of the research will be better because the element of data representation is higher and not only focuses on manufacturing companies.

It is expected that further research can be developed using other internal factors such as firm size, insider ownership, growth, asset structure, but the value of the company is not only influenced by internal factors, the value of the company is also influenced by external factors such as interest rates, rates inflation, currency exchange rates, socio-political situation, Government Policy and so on.

This study uses the Market to Book Value of Equity (MV / BVE) ratio to promote investment decisions. IOS (Investment Opportunity Set) has many proxies that can be used to assess investment decisions, so it is recommended that further research use other proxies in investment decisions, such as Total Assets Growth, Market to Book Assets Ratios, Capital Expenses to market the value of assets, and Current Assets to Total Assets.

Research Limitation. This research only considers manufacturing companies while other companies such as banking, services, property, trade, mining and agriculture are not considered so that they cannot be generalized to all companies in Indonesia. This study uses a small number of samples and focuses on the 2013-2016 period, so it cannot be known whether the results of the study will be different if the period of time is long. There are many factors that can influence a company's value, including: internal and external factors. In this study only examined the internal factors of the company, namely four independent variables that can affect the value of the company.

\section{REFERENCES}

1. Aggarwal, Divya., and Padha, Purna Chandra. 2017. Impact of Capital Structure on Firm Value: Evidence from Indian Hospitality Industry. Theoretical Economics Letters, 2017, 7, 982-1000. http://www.scirp.org/journal/tel. ISSN Online: 2162-2086. ISSN Print: 2162-2078.

2. Anton, Sorin Gabriel. 2016. The Impact of Dividend Policy On Firm Value. A Panel Data Analysis Of Romanian Listed Firms. Journal of Public Administration, Finance and Law.

3. Ayuningtias, Dwi. 2013. Pengaruh Profitabilitas terhadap Nilai Perusahaan: Kebijakan Dividen dan Kesempatan Investasi Sebagai Variabel Antara. Jurnal IImu dan Riset Akuntansi, 1(1): h: 37-57.

4. Budagaga, Akram. 2017. Dividend Payment and its Impact on the Value of Firms Listed on Istanbul Stock Exchange: A Residual Income Approach. ISSN: 2146-4138. available at http: www.econjournals.com. International Journal of Economics and Financial Issues, 2017, 7(2), 370-376.

5. Budiandriani dan Mahfudnurnajamuddin. 2014. The Influence of Intellectual Capital Components to Financial Performance and Value of the Firm Registered in Indonesia Stock Exchange. Research in Applied Economics, 6(1), pp: 216-224.

6. Brigham, E.F., dan J. Houston. 2001. Manajemen Keuangan. Penerjemah Hermawan Wibowo. Edisi Kedelapan. Edisi Indonesia. Buku II. Jakarta:Erlangga.

7. Chen, C. K. 2004. Research on impacts of team leadership on team effectiveness. The Journal of American Academy of Business, Cambridge, 266-278.

8. Cheryta, Aldea Mita., Moeljadi., and Indrawati, Nur Khusniyah. 2017. The Effect of Leverage, Profitability, Information Asymmetry, Firm Size on Cash Holding and Firm 
Value of Manufacturing Firms Listed at Indonesian Stock Exchange. International Journal of Research in Business Studies and Management. Volume 4, Issue 4, 2017, PP 21-31. ISSN 2394-5923 (Print) \& ISSN 2394-5931 (Online). http://dx.doi.org/10.22259/ijrbsm.0404004.

9. Dewi, Putu Yunita Saputri, Gede Adi Yuniarta, dan Ananta Wikrama Tungga Atmadja. 2014. Pengaruh Struktur Modal, Pertumbuhan Perusahaan dan Profitabilitas terhadap Nilai Perusahaan pada Perusahaan LQ 45 di BEI periode 2008-2012. E-Journal S1 Ak Universitas Pendidikan Ganesha,2 (1): 1-10.

10. Fenandar, Gany Ibrahim dan Surya Raharja. 2012. Pengaruh Keputusan Investasi, Keputusan Pendanaan dan Kebijakan Dividen Terhadap Nilai Perusahaan. Diponegoro Journal Of Accounting Vol : 1 No. 2 Hal 1-10.

11. Guizani, Moncef,. and Abaoub, Ezzeddine. 2012. Does the contribution of dividend to firm value depend on controlling shareholders?. International Journal of Disclosure and Governance Vol. 9, 1, 62-77. www.palgrave-journals.com/jdg/.

12. Hasnawati, Sri. 2005. "Dampak Set Peluang Investasi terhadap Nilai Perusahaan di Bursa Efek Jakarta", JAAI, Volume 9 No. 2, Desember: 117-126, Fakultas Ekonomi Universitas Lampung.

13. Hermuningsih, Sri. 2012. Pengantar Pasar Modal Indonesia. Yogyakarta: UPP STIM YKPN.

14. Hermuningsih, Sri. 2013. Profitability, Growth Opportunity, Capital Structure And The Firm Value. Bulletin of Monetary, Economics and Banking, October 2013. hermun_feust@yahoo.co.id. Oktober, pp.127-148.

15. Juhandi, Nendi, Made Sudarma, Siti Aisyah, dan Rofiaty. 2013. The Effects of Internal factors and Stock Ownership Structure in Dividend Policy on Company's Value (a Study on Manufacturing Companies Listed on the Indonesia Stock Exchange). International Journal of Business and Management Invention, 2(1): pp: 06-18.

16. Kusumajaya, Dewa Kadek Oka, 2011,'Pengaruh Struktur Modal dan Pertumbuhan Perusahaan terhadap Profitabilitas dan Nilai Perusahaan pada Perusahaan Manufaktur di Bursa Efek Indonesia.' Tesis Program Studi Magister Manajemen Universitas Udayana, Denpasar.

17. Kouki, Mondher and Hatem ben Said. 2011. Does Management Ownership Explain The Effect of Leverage on Firm Value? An Analysis of French Listed Firms. Journal of Business Studies Quarterly. 3(1): pp: 169-186.

18. Lintner, J. 1956. Distribution of Incomes of Corporations Among Dividens, Retained Earnings, and Taxes. American Economics Review 46: 97-113.

19. Mardiyati, U., Ahmad, G. N., dan Putri, R. 2012. Pengaruh Kebijakan Dividen, Kebijakan Hutang dan Profitabilitas Terhadap Nilai Perusahaan Manufaktur Yang Terdaftar Di Bursa Efek Indonesia (BEI) Periode 2005-2010. Jurnal Riset Manajemen Sains Indonesia (JRMSI), 3(1). h: 1-17.

20. Mahdaleta, Ela., Muda, Iskandar., and Nasir, Gusnardi Muhammad. 2016. Effects of Capital Structure and Profitability on Corporate Value with Company Size as the Moderating Variable of Manufacturing Companies Listed on Indonesia Stock Exchange. Academic Journal of Economic Studies. Vol. 2, No.3, September 2016, pp. 30-43 ISSN 2393-4913, ISSN On-line 2457-5836.

21. Malik, Muhammad Shaukat., and Maqsood, Madeeha. 2015. Impact of Changes in Dividend Policy on Firm's Value: A Case Study of Cement Sector of Pakistan. ISSN 2356-8879. Journal of Basic Sciences and Applied Research. www.textroad.com.

22. Manjunatha.K, Mr. 2013. Impact Of Debt-Equity And Dividend Payout Ratio On The Value Of The Firm. G.J. C.M.P., Vol. 2(2) 2013:18-27. ISSN 2319 - 7285. Global journal of commerce and management perspective. (www.gifre.org).

23. Manurung, Shinta D., Suhadak., dan Nuzula, Nila Firdausi. 2014. The Influence Of Capital Structure On Profitability And Firm Value (A Study on Food and Beverage Companies listed in Indonesia Stock Exchange 2010-2012 period). Jurnal Administrasi Bisnis (JAB) | Vol. 7 No. 2. administrasibisnis.studentjournal.ub.ac.id.

24. Marangu, Kenneth dan Ambrose Jagongo. 2014. Price to Book Value Ratio and 
Financial Statement Variables (An Empirical Study of Companie Quyoted At Nairobi Securities Exchange Kenya). Global Journal of Commercer \& Management Perspective, 3(6): pp: 50-56.

25. Modigliani, Franco \& Miller, Merton H. 1963. Corporate Income Taxes and the Cost of Capital: A Correction. American Economic Review, 53, 433-443.

26. Myers, Stewert C. 1977. Determinant Of Corporate Borrowing. Journal of Financial Economics.

27. Myers, S.C., 1984. The Capital Structure Puzzle, Journal of Finance. Vol. 39, hal: 572592.

28. Nasrum, Muhammad. 2013. The Influence Of Ownership Structure, Corporate Governance, Investment Decision, Financial Decision And Dividen Policy On The Firm Manufacturing Companies Listed On Indonesian Stock Exchange. Journal Managerial, 1(1): pp: 1-12.

29. Nurhayati, Mafizatun. 2013. Profitabilitas, Likuiditas dan Ukuran Perusahaan Pengaruhnya terhadap Kebijakan Dividen dan Nilai Perusahaan Sektor Non Jasa. Jurnal Keuangan dan Bisnis.

30. Nurmalasari, Indah. 2002. Analisis pengaruh faktor Profitabilitas terhadap Harga saham emiten LQ45 yang tercatat di Bursa Efek Jakarta periode 2005-2008. Jurnal Ekonomi dan Manejemen, 7(3): h: 67-98.

31. Nwamaka, Ozuomba Chidinma., and Ezeabasili, Prof. 2017. Effect of dividend policies on firm value: Evidence from quoted firms in Nigeria. International Journal of Management Excellence Volume 8 No.2 February 2017. ISSN : 2292-1648.

32. Pratiska, Ni Gst A Pt Silka. 2012. Pengaruh IOS, Leverage, dan Dividen Yield terhadap Profitabilitas dan Nilai Perusahaan Sektor Manufaktur di BEl. Jurnal Manajemen. Pp: 147-173.

33. Pujiati, Diyah dan Widanar, Erman. 2009. Pengaruh Struktur Kepemilikan Terhadap Nilai Perusahaan: Keputusan Keuangan sebagai Variabel Intervening. Jurnal Ekonomi Bisnis dan Akuntansi Ventura, Vol. 12. No.1, hal. 71-86.

34. Purwanto, P., and Agustin, Jillian. 2017. Financial Performance towards Value of Firms in Basic and Chemicals Industry. European Research Studies Journal Volume XX, Issue 2A,. pp. 443-460.

35. Rachmawati, Andri dan Triatmoko Hanung. 2007. Analisis Faktor-faktor yang Mempengaruhi Kualitas Laba dan Nilai Perusahaan. SNA X, Makasar 26-28 Juli 2007.

36. Rasyid, Abdul. 2015. Effects of ownership structure, capital structure, profitability and company's growth towards firm value. International Journal of Business and Management Invention. ISSN (Online): 2319- 8028, ISSN (Print): 2319 - 801X. www.ijbmi.org || Volume 4 Issue 4|| April. 2015 || PP-25-31.

37. Rehman, Obaid Ur. 2016. Impact of Capital Structure and Dividend Policy on Firm Value. Journal of Poverty, Investment and Development (www.iiste.org). ISSN 2422846X An International Peer-reviewed Journal. Vol.21.

38. Robert Ang. 1997. Buku Pintar Pasar Modal Indonesia, Mediasoft Indonesia, Jakarta.

39. Sabrin., Sarita, Buyung., Takdir S, Dedy., dan Sujono. 2016. The Effect of Profitability on Firm Value in Manufacturing Company at Indonesia Stock Exchange. The International Journal Of Engineering And Science (IJES) || Volume || 5 || Issue || 10 || Pages || PP 81-89 || 2016 || ISSN (e): 2319 - 1813 ISSN (p): 2319 - 1805.

40. Salvatore, Dominick. 2011. Ekonomi Manajerial dalam Perekonomian Global. Buku I Edisi kelima. Jakarta: Salemba Empat.

41. Safrida, Eli. 2008. Pengaruh Struktur Modal dan Pertumbuhan Perusahaan Terhadap Nilai Perusahaan Pada Perusahaan Manufaktur Di Bursa Efek Jakarta. Thesis. (online), (www.google.com).

42. Sartono, R.A. 2001. Manajemen Keuangan Teori dan Aplikasi. Edisi 4. Yogyakarta: BPFE.

43. Slater, Stanley F and Zwirlein Thomas J. 1996. The Structure of Financial Strategy: Patterns in Financial Decision Making. Journal of Managerial and Decesion Economics (1986-1998), Vol. 17, No.3 pp. 253. 
44. Sujoko dan Subiantoro. 2007. Pengaruh Kepemilikan Saham, Laverage, Faktor Intern dan Faktor Ektern Terhadap Nilai Perusahaan (Studi Emperik Pada Perusahaan Manufaktur di Bursa Efek Jakarta). Jurnal Manajemen dan Kewirausahaan, Nol 9, No.1, hal 41-48.

45. Sudiyatno, Bambang, Elen Puspitasari, dan Andi Kartika. 2012. The Company's Policy, Firm Performance, and Firm Value: An Empirical Research on Indonesia Stock Exchange. American International Journal of Coutemporary Research, 2(12): pp: 30-40.

46. Sugiyono. 2013. Metode Penelitian Bisnis (Pendekatan Kuantitatif, Kualitatif,dan R\&D). Bandung: Alfabeta.

47. Suguhen. 2003. Pengaruh Struktur Modal Terhadap Produktivitas Aktiva dan Kinerja Keuangan Serta Nilai Perusahaan Industri Manufaktur di Indonesia.Disertasi. (online), (www.google.com).

48. Supratiningrum dan Sabat Nugroho Asji. 2013. Pengaruh Moderasi Pengungkapan Corporate Social Responsibility (CSR) dan Good Corporate Government (GCG) Terhadap Hubungan Return On Equity (ROE) dan Nilai Perusahaan. H: 83-97.

49. Velnampy, T dan J.A. Niresh. 2012. The Relationship between Capital Structure and Profitability. Global Journal of Management and Business Research. Vol 12 Issue 13 2012. pp. 66-74.

50. Vidhya Priya, Dr. P. and Mohanasundari, Dr. M. 2016. Dividend Policy and Its Impact on Firm Value: A Review of Theories and Empirical Evidence. Journal of Management Sciences and Technology, 3 (3), June - 2016. ISSN -2347-5005.

51. Wiagustini, Ni Luh Putu. 2014. Dasar-dasar Manajemen Keuangan. Udayana University Pers.

52. Winarto, Jacinta. 2015. The Determinants of Manufacturer Firm Value in Indonesia Stock Exchange. International Journal of Information, Business and Management, Vol. 7, No.4.

53. Wirawati. 2008. Pengaruh Faktor Fundamental Terhadap Price Book Value Dalam Penilaian Saham DI Bursa Efek Jakarta Dalam Kondisi Krisis Moneter, Buletin Studi Ekonomi Volume 13 No.1. www.idx.co.id

54. Zahro, Nafi Inayati. 2009. Analisis Pengaruh Set Kesempatan Investasi Terhadap Kebijakan Dividen dan Leverage Perusahaan. Jurnal Sosial dan Budaya Kudus. 